\title{
Letters to the editors
}

\section{Interleukin-1 $\beta$ and GTP-binding proteins}

\section{Dear Sir,}

I would like to comment on the report by Rabuazzo et al. [1], in which the authors claim that they have evidence for the involvement of an inhibitory pertussis toxin (PTX)-sensitive GTP-binding protein in interleukin- $1 \beta$ (IL-1 $\beta$ ) suppression of insulin secretion from rat pancreatic islets.

IL- $1 \beta$ is well-known to exert cytotoxic and cytostatic effects on beta cells from isolated rodent islets [2], and the cytokine is secreted by macrophages infiltrating the islets preceding clinically overt insulin-dependent diabetes mellitus (IDDM) [3]. In order to ultimately find a means of intervening in the development of IDDM, it is of paramount importance to establish the subcellular mechanisms by which IL- $1 \beta$ exerts its inhibitory actions in the beta cell. Interference with PTX-sensitive inhibitory GTP-binding proteins [4] is an attractive hypothesis, which has been shown to partially account for the suppression of insulin secretion by epinephrine, somatostatin, galanin and E-type prostaglandins [5]. At least seven $\mathrm{G} \alpha$ subunits have been identified in rat islets by polymerase chain reaction strategies and in situ hybridization [6].

However, for a number of reasons, I find it hard to subscribe to the concept of IL- $1 \beta$ acting through such GTP-binding proteins. Previous studies $[7,8]$ which were subsequently confirmed $[9,10]$, have shown that PTX is unable to prevent the inhibitory action of IL- $1 \beta$ on insulin secretion from isolated rat islets. Importantly, and in contrast to IL- $1 \beta$, PTX (from the same batch, used at the same concentration and during the same time frame) blocked inhibition of rat islet beta-cell mitogenesis and insulin secretion evoked by $\alpha$-adrenoreceptor agonists [11]. Incidentally, both $\mathrm{IL}-1 \beta$ and $\alpha$-adrenergic agonists lowered the islet content of cyclic AMP [7, 10-13]. However, neither a specific activator of protein kinase A, the cell-permeant Sp-cAMP[S], nor PTX (which increased islet cyclic AMP), were able to protect against the inhibition of insulin secretion and beta-cell proliferation evoked by IL-1 $\beta$, as opposed to the case for $\alpha$-adrenergic agonists $[7,10,11]$. In their

Corresponding author: Dr. Å. Sjöholm, Department of Molecular Medicine, The Endocrine and Diabetes Unit, The Rolf Luft Center for Diabetes Research, Karolinska Institute, S17176 Stockholm, Sweden entirety, my feeling is that these data suggest that inhibitory heterotrimeric GTP-binding proteins connected to adenylyl cyclase convey the inhibitory signals of $\alpha$-adrenergic agonists, but not those of IL-1 $\beta$, in the beta cell.

I am particularly concerned with the enormous concentrations of PTX and cholera toxin needed by Rabuazzo et al. [1], to reverse the impact of IL- $1 \beta$. It should be noted that in their original studies with PTX, Katada and Ui [13] demonstrated reversibility of inhibition of insulin secretion with as little as $1 \mathrm{pg} / \mathrm{ml}$ of PTX; half-maximal recovery was recorded at $100 \mathrm{pg} / \mathrm{ml}$, and levelling-off at $10 \mathrm{ng} / \mathrm{ml}$ of PTX. By contrast, Rabuazzo et al. [1] needed PTX concentrations as high as $0.5-$ $2 \mu \mathrm{g} / \mathrm{ml}$ to detect a partial protective effect, whereas lower concentrations did not cause any significant effects [1]. Thus, one may want to entertain the idea that such heroic concentrations of toxin, amounting to $\approx 10^{6}$-times those needed by others [ 13$]$ to significantly reverse inhibition of insulin secretion, may cause toxicity or other effects totally unrelated to influences on GTP-binding proteins. Additionally, it is evident from Table 1 that, at these concentrations, both cholera toxin and PTX had stimulatory effects of their own on insulin secretion [1]. Furthermore, it is well-known that PTX needs several hours to express its effects on the GTP-binding proteins [13]. This is the reason why islets were pretreated with the toxin in the papers by Sjöholm $[7,8,10]$ and Eizirik et al. [9]. In order to arrive at the conclusion that IL- $1 \beta$ indeed exerts its action partially through interference with PTX-sensitive GTP-binding proteins, Rabuazzo et al. [1] may want to strengthen their case by demonstrating: 1 ) a GTP requirement for IL-1 $\beta$ effects in beta-cell membrane preparations, 2) stimulation of a betacell GTPase by IL- $1 \beta$, 3) the presence of an IL- $1 \beta$-specific PTX substrate, 4) that GTP- $\gamma$-[S] inhibits the rate of PTX-catalysed ADP-ribosylation of such a particular substrate and 5) that, conversely, GDP- $\beta$-[S] would stimulate such an activity.

Other questions that one would like to have seen addressed include how rates of hormone secretion recorded were related to possible effects of $I L-1 \beta$ and the toxins on islet insulin and DNA contents. One possibility is that these huge concentrations of toxins may functionally impair the $\mathrm{IL}-1 \beta$ molecule, and it would be interesting to know how the authors have excluded this possibility. Additionally, the choice of statistical analysis appears inappropriate: in the multiple comparisons made in the study by Rabuazzo et al. [1] analysis of variance should be performed. What are the changes in islet cAMP con- 
tent after culture in the toxins, and why it is that forskolin cannot reverse the IL-1 $\beta$ effects when cholera toxin purportedly can? Finally, I find it hard to follow the argument [1] that differences in glucose metabolism known to exist between normal and tumoural beta-cells $[8,14]$ would account for the different responses to PTX. By contrast, it is IL- $1 \beta$ and not PTX (Table 2 [1]) that affects glucose oxidation rates, whereas the inhibitory effects of IL- $1 \beta$ remain qualitatively similar between normal $[7,9,10]$ and tumoural $[8,15]$ beta cells.

Thus, the line of objections outlined above makes me feel that it remains ambiguous, at best, whether $\mathrm{IL}-1 \beta$ indeed acts specifically through PTX-sensitive GTP-binding proteins in suppressing beta-cell function. However, this by no means contradicts the possibility that the cytokine interferes with GTPbinding proteins not sensitive to PTX, as has been shown in other tissues [16].

Yours sincerely,

A. Sjöholm

\section{References}

1. Rabuazzo AM, Buscema M, Caltabianco Vet al. (1995) Interleukin- $1 \beta$ inhibition of insulin release in rat pancreatic islets possible involvement of G-proteins in the signal transduction pathway. Diabetologia 38: 779-784

2. Bendtzen K (1989) Immune hormones (cytokines); pathogenic role in autoimmune rheumatic and endocrine diseases. Autoimmunity 2: 177-189

3. Jiang Z, Woda BA (1991) Cytokine gene expression in the islets of the diabetic biobreeding/Worcester rat. J Immunol 146: 2990-2994

4. Neer E (1995) Heterotrimeric G-proteins: organizers of transmembrane signals. Cell 80: 249-257

5. Robertson RP, Seaquist ER, Walseth TF (1991) G proteins and modulation of insulin secretion. Diabetes 40: 1-6

6. Zigman JM, Westermark GT, LaMendola J, Steiner DF (1994) Expression of cone transducin, $\mathrm{G}_{\mathrm{z}} \alpha$, and other $\mathrm{G}$ -

\section{Response from the authors}

\begin{abstract}
Dear Sir,
Dr. Sjöholm disagrees with our recent report [1] that G-proteins may be involved in the inhibition of insulin release by interleukin-1 $\beta$ (IL-1 $\beta$ ). He raises several points that I would like to address. The main criticism relates to the dose of pertussis toxin (PTX) that we have used, 'scientifically' defined as 'heroic' by Dr. Sjöholm. We found a detectable effect at $0.2 \mu \mathrm{g}$ ' $\mathrm{ml}$, and a plateau at $0.5 \mu \mathrm{g} / \mathrm{ml}$. From the literature it is evident that a range of concentrations from $0.01-0.05[2,3]$ to $0.1-$ $1 \mu \mathrm{g} / \mathrm{ml}[4,5]$ has been used. Several reasons may account for this broad range, from different PTX preparations to different cell lines or experimental protocols. However, I would like to stress here that different $\mathrm{G}$-proteins may have a different sensitivity to PTX. ADP ribosylation by pertussis toxin has been
\end{abstract}

Corresponding author: Dr. F. Purrello, Cattedra di Endocrinologia, Ospedale Garibaldi, Piazza S. Maria di Gesù, I-95123 Catania, Italy protein $\alpha$-subunit messenger ribonucleic acids in pancreatic islets. Endocrinology 135: 31-37

7. Sjöholm $\AA$ (1991) Inhibition of fetal rat pancreatic $\beta$-cell replication by interleukin- $1 \beta$ in vitro is not mediated through pertussis toxin-sensitive G-proteins, a decrease in cyclic AMP, or protease activation. FEBS Lett 289: 249-252

8. Sjöholm A (1991) Cytokines inhibit rat insulinoma cell proliferation and insulin secretion non-synergistically and in a pertussis toxin-insensitive manner. Immunol Lett 30: 81-86

9. Eizirik DL, Tracey DE, Bendtzen K, Sandler S (1992) Role of receptor binding and gene transcription for both the stimulatory and inhibitory effects of interleukin- 1 in pancreatic $\beta$-cells. Autoimmunity 12: 127-133

10. Sjöholm $\AA$ (1992) Differential effects of cytokines on longterm mitogenic and secretory responses of fetal rat pancreatic $\beta$-cells. Am J Physiol 263: C114-C120

11. Sjöholm $\AA$ (1991) $\alpha$-Adrenergic inhibition of rat pancreatic $\beta$-cell replication and insulin secretion is mediated through a pertussis toxin-sensitive G-protein regulating islet cAMP content. Biochem Biophys Res Commun 180: 152-155

12. Sandler S, Bendtzen K, Eizirik DL, Strandell E, Welsh M, Welsh N (1990) Metabolism and $\beta$-cell function of rat pancreatic islets exposed to human interleukin- $1 \beta$ in the presence of a high glucose concentration. Immunol Lett 26: 245-252

13. Katada T, Ui M (1980) Slow interaction of islet-activating protein with pancreatic islets during primary culture to cause reversal of $\alpha$-adrenergic inhibition of insulin secretion. J Biol Chem 255: 9580-9588

14. Sjöholm $\AA$, Welsh N, Bankston PW, Hoftiezer V, Hellerström C (1991) Increased glucose oxidation and contents of insulin and ATP in polyamine-depleted rat insulinoma cells (RINm5F). Biochem J 277: 533-540

15. Sandler S, Bendtzen K, Eizirik DL, Sjöholm $\AA$, Welsh N (1989) Decreased cell replication and polyamine content in insulin-producing cells after exposure to human interleukin-1 $\beta$. Immunol Lett 22: 267-272

16. O'Neill LAJ, Bird TA, Saklatvala J (1990) Interleukin-1 signal transduction. Immunol Today 11: 392-394

demonstrated for $\mathrm{G}_{\mathrm{i}}$ (which inactivates adenylcyclase), $\mathrm{G}_{\mathrm{k}}$ (which opens $\mathrm{K}^{+}$channels), $\mathrm{G}_{\mathrm{plc}}$ (which activates phospholipase $C$ ), $G_{p l a}$ (which activates phospholipase $A$ ), $G_{1}$ (transducin) and $G_{0}$ (function uncertain) [6]. The PTX dose that interacts with $G_{i}$ in pancreatic islets may be different from the PTX dose that interacts with $G_{k}$ or $G_{p l c}$ In addition, the PTX sensitivity of the different $G$-proteins may change in the different experimental models (RIN, HIT, fetal or adult rat islets). Dr. Sjöholm reports $[7,8]$ that PTX (at a single concentration) blocked inhibition of insulin release evoked by alpha-adrenoreceptor agonists and not by IL-1 $\beta$; in my opinion this simply suggests that alpha-adrenoreceptor agonists and IL- $1 \beta$ may interact with different G-proteins. To summarise, therefore, I totally disagree with the comment that we have used 'concentrations of toxin amounting to $\sim 10^{6}$ times those needed by others', and I find it more interesting to understand the scientific reasons to explain the different PTX concentrations used, to gain further information on the IL- $1 \beta$ mechanism of action. Other criticisms relate to the choice of statistical analysis (using the analysis of variance, the results of Table 1 and 2 would be similar), and to some speculation in the Discussion (differences in glucose metabolism known to exist between normal 
and tumoural cells seem to be due to different isoenzyme expression or activity. PTX-sensitive G-proteins may differently influence these enzymes).

In our report, from the Title to the Discussion we emphasise that we are only in a preliminary phase, and that the precise G-protein(s) involved as effector in this system is unknown. A series of more direct studies is now possible using our experimental model, to better clarify the role of G-proteins in mediating IL- $1 \beta$ effects on pancreatic islets.

Yours sincerely,

F.Purrello

\section{References}

1. Rabuazzo AM, Buscema M, Caltabiano Vet al. (1995) Interleukin- $1 \beta$ inhibition of insulin release in rat pancreatic islets. Possible involvement of $G$-proteins in the signal transduction pathway. Diabetologia 38: 779-784

2. Nilsson T, Arkhammar P, Rorsman P, Berggren PO (1989) Suppression of insulin release by galanin and somatostatin is mediated by a G-protein. An effect involving repolarization and reduction in cytoplasmic free $\mathrm{Ca}^{2+}$ concentration. $\mathrm{J}$ Biol Chem 264: 973-880
3. Schmidt A, Hescheler J, Offermanns S et al. (1991) Involvement of pertussis toxin-sensitive G-proteins in the hormonal inhibition of dihydropyridine-sensitive $\mathrm{Ca} 2+$ currents in an insulin-secreting cell line (RINm5F). J Biol Chem 266: 18025-18033

4. Hsu WH, Xiang H, Rajan AS, Kunze DL, Boyd III AE (1991) Somatostatin inhibits insulin secretion by a G-protein-mediated decrease in $\mathrm{Ca}^{2 *}$ entry through voltage-dependent $\mathrm{Ca}^{2+}$ channels in the beta cell. J Biol Chem 266: 837-843

5. Cormont M, Le Marchand-Brustel $\mathrm{Y}$, Van Obberghen E, Spiegel AM, Sharp GWG (1991) Identification of G-protein alpha-subunits in RINm5F cells and their selective interaction with galanin receptor. Diabetes 40: 1170-1176

6. Robertson RP, Seaquist ER, Walseth TF (1991) G proteins and modulation of insulin secretion. Diabetes 40: 1-6

7. Sjöholm A (1992) Differential effects of cytokines on longterm mitogenic and secretory responses of fetal rat pancreatic beta-cells. Am J Physiol 263: C114-C120

8. Sjöholm A (1991) Alpha-adrenergic inhibition of rat pancreatic $\beta$-cell replication and insulin secretion is mediated through a pertussis toxin-sensitive G-protein regulating islet cAMP content. Biochem Biophys Res Commun 180: 152155

\section{Large-scale study of an A-to-G transition at position 3243 of the mitochondrial gene and IDDM in Japanese patients}

\section{Dear Sir,}

The most frequent gene mutation in Japanese patients with non-insulin-dependent diabetes mellitus (NIDDM) was recently reported to be an A-to-G transition at position 3243 of the mitochondrial gene (3243 base pair (bp) mutation) $(\sim 1 \%)$. Otabe et al. [1] and Odawara et al. [2] identified it in 5 of 550 NIDDM patients and 3 of 300 NIDDM patients who also had impaired glucose tolerance (IGT). It seems that approximately $1 \%$ of the cases of NIDDM in Japanese patients may be strongly associated with and/or caused by the $3243 \mathrm{bp}$ mitochondrial gene mutation. On the other hand, Oka et al. [3] reported that approximately $10 \%$ of patients with slowly progressive insulin-dependent diabetes (IDDM), which was characterized by a clinical course including a period of several years without insulin treatment, decreasing C-peptide response and long-term islet cell antibody positivity, had the $3243 \mathrm{bp}$ mitochondrial mutation. Indeed, it is sometimes difficult to determine the type of diabetes in lean young Japanese patients because they sometimes exhibit a low C-peptide response which requires insulin treatment without abrupt onset of diabetes, and proneness to ketosis. We recently reported that 6 of $102(5.9 \%)$ lean female patients who developed NIDDM at a young age (25.0 46.3 years) had the $3243 \mathrm{bp}$ mitochondrial mutation; these six patients were diagnosed as having insulin-requiring NIDDM because they did not exhibit abrupt onset of diabetes or keto-

Corresponding author: Dr. Y. Uchigata, Diabetes Center, Tokyo Women's Medical College, 8-1 Kawada-cho, Shinjuku-ku, Tokyo 162, Japan sis/ketoacidosis. Moreover, we reported that none of 64 IDDM patients had the $3243 \mathrm{bp}$ mutation [4]. Although Odawara et al. [2] reported a similar finding (among 94 IDDM patients no patients with the $3243 \mathrm{bp}$ mutation were found), it is difficult to support statistically the lack of an association between the 3243 bp mutation and IDDM development based only on such small-scale studies of IDDM patients. Therefore, we conducted a large-scale study to investigate whether patients with well-defined IDDM possess the 3243 bp mutation which might produce autoimmunity leading to IDDM.

The study population $(n=568$, male/female $=203 / 365$ [5]) comprised 489 IDDM patients who were residents of the Tokyo area treated at the Diabetes Center, Tokyo Women's Medical College, $29 \mathrm{LDDM}$ patients treated at several hospitals who were residents of the "Hokkaido" area and 50 IDDM patients treated at the Department of Geriatric Medicine, Osaka University Medical School who were residents of the Osaka area. The diagnosis of IDDM was based on the criteria of the National Diabetes Data Group with a further requirement of low C-peptide values. The 3243 bp mutation in mitochondrial DNA extracted from peripheral blood cells was detected using the polymerase chain reaction (PCR) method with a probe specific to this mutation [6]; the PCR products were digested with the restriction endonuclease Apa I followed by silver staining [4]. Using this method we detected $0.6 \%$ heteroplasmy of the mutation [4].

Table 1 shows the baseline characteristics of the IDDM patients divided into four groups. Some of them had parents with NIDDM or siblings with IDDM. The frequency of coma or ketoacidosis at the time of diagnosis showed significant differences in age at onset $(p<0.002)$. The greater the age at onset, the less frequent was coma or ketoacidosis at the time of diagnosis. The $3243 \mathrm{bp}$ mutation was not detected in any of the IDDM patients $(p=0.0285$ vs 5 of 550 NIDDM patients [1] and $p=0.0418$ vs 3 of 300 NIDDM + IGT patients [2] by Fisher's exact probability analysis). The result of this study demon- 